\title{
THE ESTIMATION OF BZ55 AND SULPHONAMIDES IN BLOOD SUGAR FILTRATES
}

\author{
BY \\ D. G. MOSS \\ From the Department of Pathology, Withington Hospital, Manchester
}

(RECEIVED FOR PUBLICATION MARCH 28, 1957)

Following reports by Franke and Fuchs (1955) and by Bertram, Bendfeldt, and Otto (1955) that oral administration of the sulphonamide $\mathrm{N}_{1}$ sulphanilyl- $\mathrm{N}_{2}-\mathrm{n}$-butylcarbamide could successfully control diabetes, considerable interest has centred on this compound. It has been used on a large scale in Germany, with apparently successful results, in a proportion of cases, chiefly elderly non-ketonic diabetics. Clinical trials in Britain, however (Duncan, Baird, and Dunlop, 1956 ; Walker, Leese, and Nabarro, 1956), have suggested that the limited utility of the compound is outweighed by its potentially toxic properties. A considerable amount of research work is proceeding, and it seems likely that other compounds of related structure will be synthesized and tested for their antidiabetic effect.

The present work arose from the observation that Bratton and Marshall's (1939) method for sulphonamide estimation could not be applied to the filtrate used in the modified Schaffer-Hartmann blood sugar method of King, Haslewood, and Delory (1937) and King, Haslewood, Delory, and Beall (1942). Bratton and Marshall's method, carried out on these filtrates, produces a deep blue which effectively masks the purple of the final azo dye. The blue apparently results from the reaction of nitrous acid with free tungstate followed by further reaction with the coupling agent, N(1naphthyl)ethylenediamine dihydrochloride. It was found that this effect could be avoided by using $\mathrm{N}$-sulphatoethyl-m-toluidine as the coupling agent. The latter substance is also more stable, both in solid form and in solution, than N(1-naphthyl)ethylenediamine, and has the further advantage that it does not combine with free nitrous acid, and it is therefore not necessary to add ammonium sulphamate to remove nitrous acid before coupling.

The present method permits of simultaneous estimations of sugar and sulphonamides on a $0.2 \mathrm{ml}$. specimen of capillary blood.
Coupling with $\mathrm{N}$-sulphatoethyl-m-toluidine gives orange-coloured solutions. The absorption spectrum of the compound obtained with $\mathrm{N}_{1}$ sulphanilyl- $\mathrm{N}_{2}-n$-butylcarbamide (BZ55) shows that maximum light absorption was $495 \mathrm{~m} \mu$. Extinction coefficients measured at this wavelength were comparable to those of the purple dyes produced in Bratton and Marshall's method (readings at $545 \mathrm{~m} \mu$ ). Beer's law was obeyed up to concentrations of BZ55 equivalent to blood levels of about $20 \mathrm{mg}$. $/ 100 \mathrm{ml}$.

The table shows the recoveries of BZ55 added to normal blood. Recoveries varied from $81 \%$

TABLE

RECOVERIES OF BZ5S ADDED TO NORMAL BLOOD

\begin{tabular}{|c|c|c|c|c|c|c|c|}
\hline $\begin{array}{l}\mu \mathrm{g} \text {. added to } C \\
\mu \mathrm{g} \text {. found } \\
\% \text { recovery }\end{array}$ & $\begin{array}{c}\cdot 2 \mathrm{ml} \\
\ldots \\
\ldots\end{array}$ & \begin{tabular}{cc|} 
whole blood \\
$\ldots$ & $\ldots$ \\
$\ldots$ & $\ldots$
\end{tabular} & $\begin{array}{l}8 \\
8 \cdot 5\end{array}$ & $\begin{array}{l}16 \\
14 \\
88\end{array}$ & $\begin{array}{l}24 \\
21 \cdot 5 \\
89\end{array}$ & $\begin{array}{l}32 \\
30 \cdot 5 \\
95\end{array}$ & $\begin{array}{l}40 \\
37 \cdot 5 \\
93\end{array}$ \\
\hline
\end{tabular}

to $95 \%$, the mean recovery being $89 \%$. These losses are of about the same magnitude as those reported for Bratton and Marshall's method (Hawk, Oser, and Summerson, 1947).

\section{Method}

Reagents.-The following are required :

(1) Isotonic Sodium Sulphate/Copper Sulphate Solution.-A mixture of $320 \mathrm{ml}$. of $3 \%$ sodium sulphate $\left(\mathrm{Na}_{2} \mathrm{SO}_{4} \cdot 10 \mathrm{H}_{2} \mathrm{O}\right)$ and $30 \mathrm{ml}$. of $7 \%$ copper sulphate ( $\mathrm{CuSO}{ }_{4} .5 \mathrm{H}_{2} \mathrm{O}$ ).

(2) Sodium tungstate, 10 g. per $100 \mathrm{ml}$.

(3) $N$ Hydrochloric acid.

(4) $0.1 \%$ Sodium Nitrite.-This solution should be stored in a refrigerator.

(5) $1.8 \% N$-Sulphatoethyl-m-toluidine in Water.This solution stored in a refrigerator keeps for several months, but should be discarded if a brown tint appears.

(6) Stock Standard Sulphonamide Solution.-This is made up of $15 \mathrm{mg} . \%$ BZ55 in water. 
(7) Dilute Standard Solution.-Of this, $0.75 \mathrm{mg} . \%$ is used. The stock solution is diluted 1/20.

Procedure.-Capillary blood, $0.2 \mathrm{ml}$., is washed into $3.5 \mathrm{ml}$. of isotonic sodium sulphate/copper sulphate solution and $0.3 \mathrm{ml}$. of $10 \%$ sodium tungstate added, and the mixture is centrifuged. One millilitre of the supernatant liquid is used for blood sugar estimation by the modified Schaffer-Hartmann method. BZ55 is estimated on a further millilitre of the supernatant liquid.

To $1 \mathrm{ml}$. of supernatant liquid, $0.2 \mathrm{ml}$. $\mathrm{N} \mathrm{HCl}$ is added, followed by $0.1 \mathrm{ml}$. of sodium nitrite solution. After mixing well, $2 \mathrm{ml}$. of $\mathrm{N}$-sulphatoethyl-mtoluidine solution is added. A standard is prepared by taking $1 \mathrm{ml}$. of dilute sulphonamide solution instead of the solution for analysis. The orange colours develop almost at ence and are stable for several hours. Readings should be taken at $495 \mathrm{~m} \mu$ in a spectrophotometer or in a colorimeter with the appropriate filter.

The method may be used as a routine method for the estimation of sulphonamides other than those used in the control of diabetes. In this case, protein pre- cipitation may conveniently be carried out by using $\stackrel{0}{\vec{\sigma}}$ zinc sulphate and sodium hydroxide as in King's (1946) 을 method for blood urea estimation. Whole blood, $\vec{F}$ $0.2 \mathrm{ml}$, is mixed with $3.2 \mathrm{ml}$. of isotonic sodium $\stackrel{5}{?}$ sulphate, followed by $0.3 \mathrm{ml}$. of $10 \%$ zinc sulphate and $0.3 \mathrm{ml}$. of $0.5 \mathrm{~N} \mathrm{NaOH}$. After centrifuging, the estimation is carried out on the supernatant fluid as $\frac{\bar{\sigma}}{\partial}$ before. This method of protein precipitation gives $\mathbb{\nabla}$ recoveries similar to those found for the copper tungstate method.

The author is grateful to E. Lilly and Co., Ltd., for $\vec{\circ}$ a sample of BZ55, and for much helpful advice.

\section{REFERENCES}

Bertram, F., Bendfeldt, E., and Otto, H. (1955). Dtsch. med. Wschr., ত 80,1455 .

Bratton, A. C., and Marshall, E. K. (1939). J. biol. Chem., 128, 537. $\vec{\circ}$ Duncan, L. J. P., Baird, J. D., and Dunlop, D. M. (1956). Brit. A med. J., 2, 433 .

Franke, H., and Fuchs, J. (1955). Dtsch. med. Wschr., 80, 1449.
Hawk, P. B., Oser, B. L., and Summerson, W. H. (1947). Practical Physiological Chemistry, 12th ed. Blakiston, Philadelphia.

King, E. J. (1946). Micro-analysis in Medical Biochemistry. Chur- 음 chill, London.

Haslewood, G. A. D., and Delory, G. E. (1937). Lancet, 1, 886.

- - and Beall, D. (1942). Ibid., 1, 207.

Walker, G., Leese, W. L. B., and Nabarro, J. D. N. (1956). Brit. med. J., 2, 451. 